\title{
SYNTHESIS, CHARACTERIZATION AND ANTIMICROBIAL STUDIES OF CO-ORDINATION POLYMERS
}

\author{
AMISH I. SHAH ${ }^{a}$, HEMANG M. SHUKLA ${ }^{a}$, PURVESH J. SHAH ${ }^{b}$ AND DILIPSINH S. RAJ ${ }^{*}$ \\ ${ }^{a}$ Chemistry Department, M.B. Patel Science College, Anand -388001 (India). \\ ${ }^{\mathrm{b}}$ Department of Chemistry, Shri A.N.Patel P. G.Institute, Anand-388 001(India).
}

(Received: May 14, 2012 - Accepted: August 17, 2012)

\begin{abstract}
A novel heteronuclear bis-ligand namely 5-[4-(2-carboxyphenyl carbonyl amino)-phenyl-4-carbonyl methyl amino)-8-hydroxyquinoline was synthesized and characterized. This Bis-ligand was designated as CPHQ. Co-ordination polymers of this CPHQ bis-ligand were prepared with $\mathrm{Cu}^{+2}, \mathrm{Co}^{+2}, \mathrm{Ni}^{+2}, \mathrm{Mn}^{+2}$ and $\mathrm{Zn}^{+2} \mathrm{metal}^{-}$ ions. All of these Co-ordination polymers and the CPHQ ligand were characterized by elemental analysis, IR, NMR spectral studies, thermogravimetry, electronic reflectance spectral studies and magnetic susceptibility measurement. The synthesized novel Bis-ligand and their Co-ordination polymers were screened for their antimicrobial activity.
\end{abstract}

Key Words: Heteronuclear Bis-ligand; Co-ordination polymer; spectral studies; magnetic moment; antibacterial and antifungal activities.

\section{INTRODUCTION}

The research on Co-ordination polymers by linking transition metal ions with ligands has been constantly developed in past years. Because of their excellent properties, such as semiconducting catalytic properties, waste water treatment for metal recovery, in protective coating, as antifouling paints and anti fungal properties ${ }^{1,2}$. Recently new coordination supramolecules and polymers bis(oxine), bidentate ligand based on transition metal compounds and multidentate organic ligand has attracted much interest. In this context bis(oxine) ligand with two oxine units link by a bridge of $5,5^{\prime}$ - methylene $\left(-\mathrm{CH}_{2}-\right.$ ), 5,5'-sulfonyl $\left(-\mathrm{SO}_{2}-\right), 5,5^{\prime}$-dimethylene sulfide $\left(-\mathrm{CH}_{2}-\mathrm{S}^{-} \mathrm{CH}_{2}-\right)$ and $-\mathrm{CH}_{2}$ $\mathrm{O}-\mathrm{CH}_{2}$ - are reported in literature ${ }^{3-9}$. Most of bichelating ligands are derived from well known chelating agents like 8-hydroxy quinoline and salicylic acid etc $^{3,6} .8$-Hydroxyquinoline (8-HQ) moiety has received constant consideration due to their efficient ionophores, therapeutic and fluorescences properties ${ }^{10-14}$. 8 -Hydroxyquinoline containing polymers are used in areas such as waste water treatment to recover metals, protective coatings, water disinfectants, ion-exchange resin, antifouling paints, antimicrobial, surgical materials, gels and ointment for medical uses ${ }^{15-21}$. 8-Hydroxyquinoline containing polymers and copolymers reveal complexing ability and biological activity ${ }^{22-25}$. The study of 8-quinolinol containing polyester has also been reported ${ }^{26}$. The area in which the Co-ordination polymers having bis-azo dye containing ligands has not been developed so far. Such ligand may afford the Co-ordination polymer with different properties. Hence, it was thought interesting to explore the field of Co-ordination polymers based on hetronuclearting Bis-ligand having 8-hydroxyquinoline and amic acid. Though the amic acid is generally derived by condensation of amines with anhydrides having carboxylic and amide group. The metal complexation study of various amic acids has been reported recently ${ }^{27-30}$, so the proposed present work is in connecting with the Co-ordination polymers based on hetronuclearting Bis-ligand. The synthetic route for the preparation of bis-ligand and its Co-ordination polymers are shown in scheme 1 .

\section{EXPERIMENTAL}

\section{Materials}

All the chemicals used were of analytical grade. The compound 5-amino-8hydroxyquinoline hydrochloride (AHQ) was prepared by reported methods. ${ }^{31,32}$ 4-chloro acetamido phenacyl chloride (APC) was prepared by known method. ${ }^{33}$

Synthesis of 5-[4-(2-carboxyphenyl carbonyl amino)-phenyl4-carbonyl methyl amino)-8-hydroxyquinoline (CPHQ): The 5-[4-(2-carboxyphenyl carbonyl amino)-phenyl-4-carbonyl methyl amino)-8hydroxy quinoline CPHQ was prepared in two steps.

1. Synthesis of 5-(4-phenyl carbonyl methyl amino)-8-hydroxyquinoline (PHQ): A solution of 4-chloro acetamido phenacyl chloride (APC) (24.6 g, 0.1 mole) in acetone was treated with 5-amino-8-hydroxyquinoline hydrochloride (AHQ) $(23.1 \mathrm{~g}, 0.1 \mathrm{~mole})$ in acetone at room temperature for 2.5 hours. The resultant product was filtered and hydrolyzed by $50: 50 \mathrm{HCl}$ and $\mathrm{EtOH}$ mixture.
The yield of CPHQ was $82 \%$ (20.17 g); M.p. $139-142{ }^{\circ} \mathrm{C}$ (uncorrected).

2. Synthesis of 5-[4-(2-carboxyphenyl carbonyl amino)-phenyl-4carbonyl methyl amino)-8-hydroxyquinoline (CPHQ): A solution of 5-(4-phenyl carbonyl methyl amino)-8-hydroxy quinoline (PHQ) (36.9 g, 0.1 mole) in acetone was cooled to $10^{\circ} \mathrm{C}$ and then a solution of phthalic anhydride (29.6 g, 0.2 mole) was added with constant stirring. The resulting product filtered and air-dried. The yield of CPHQ was $67 \%$ (24.72 g); M.p. 194-196 ${ }^{\circ} \mathrm{C}$ (uncorrected). Anal. Found for $\mathrm{C}_{25} \mathrm{H}_{10} \mathrm{~N}_{3} \mathrm{O}_{5}$ (441): C, 67.9; H, 4.2; N, 9.4. Calcd. C, 68.02; H, 4.30; N, 9.52. (Scheme-1)

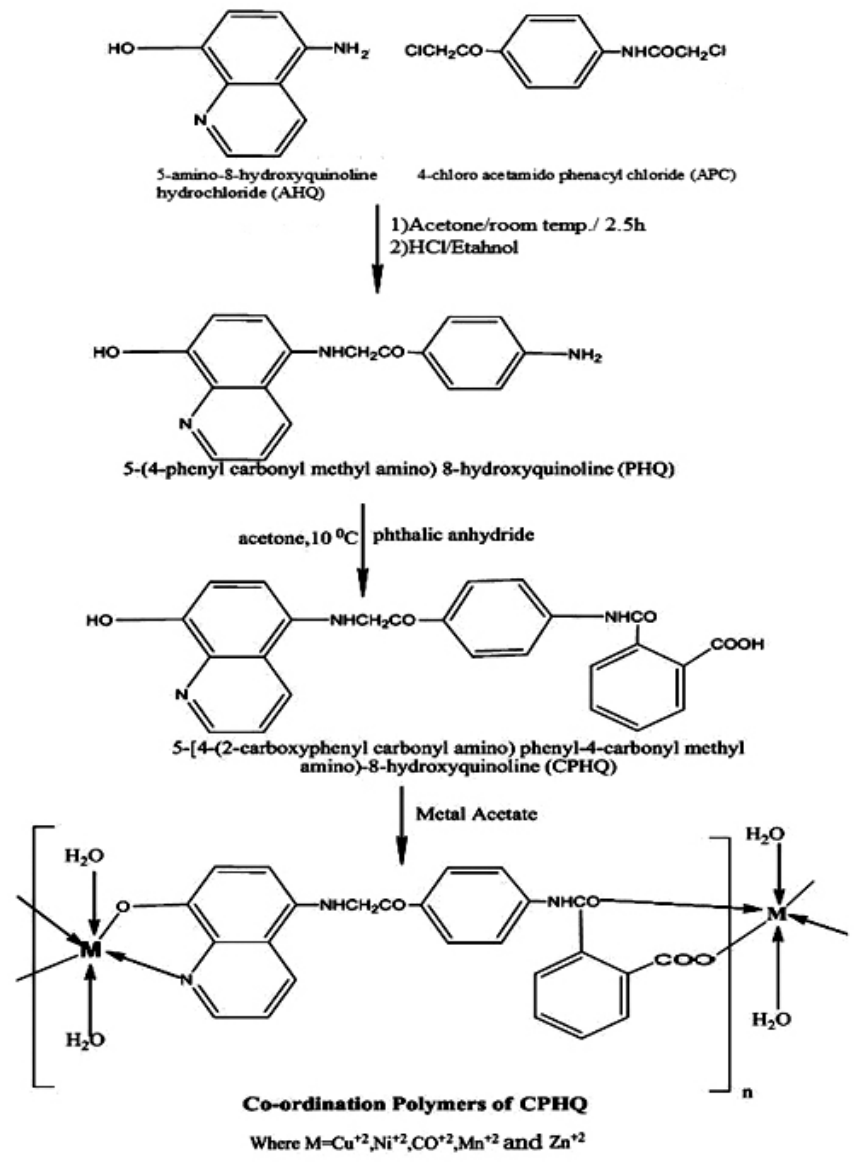

Scheme 1 


\section{PREPARATION OF CO-ORDINATION POLYMERS}

All Co-ordination polymers were synthesized by using metal acetates in a general method described as follows:

A warm and clear solution of CPHQ (4.41 g, 0.01 mole) in $20 \%$ aqueous formic acid $(200 \mathrm{~mL})$ was added to a solution of copper acetate $(1.99 \mathrm{~g}, 0.01$ mole) in $50 \%$ aqueous formic acid $(50 \mathrm{~mL})$ with constant stirring. After complete addition of metal salt solution, the $\mathrm{pH}$ of reaction mixture was adjusted to about 5 with dilute ammonia solution. Polymeric chelates were separated out in the form of suspension and then digested on a water bath for one hour and eventually filtered, washed with hot water followed by acetone and N,Ndimethyl formamide (DMF) and then dried in air at room temperature. The yields of all Co-ordination polymers were almost quantitative. The obtained solid metal complexes and their colors are shown in Table 1. The complexes are stable solids, decomposing above $258^{\circ} \mathrm{C}$ without melting and insoluble in diethyl ether, acetone, ethanol, methanol and chloroform; however, they are soluble in dimethyl sulfoxide (DMSO) and DMF.

\section{MEASUREMENTS}

Elemental analysis of CPHQ and its Co-ordination polymers were carried out on a $\mathrm{C}, \mathrm{H}, \mathrm{N}$ elemental analyzer (Italy). IR spectra of the Bis-ligand and the polymeric chelates were scanned on a Nicolet-760D FTIR spectrophotometer in $\mathrm{KBr} .{ }^{1} \mathrm{H}$ and ${ }^{13} \mathrm{C}$ NMR spectra were carried out at room temperature in DMSO- $\mathrm{d}_{6}$ and tetramethylsilane (TMS) as an internal reference using Brucker spectrophotometers (400 MHz and $100 \mathrm{MHz}$ ).

The metal content analyses of the polymeric chelates were performed by decomposing a weighed amount of each polymeric chelates followed by EDTA (disodium ethylene diamine tetra acetate) titration as reported in the literature. ${ }^{8}$
Magnetic susceptibility measurements of all the polymeric chelates were carried out at room temperature by the Gouy method. Mercury tetrathiocynatocobaltate (II) was used as a calibrantion agent. Molar Susceptibilities were corrected for diamagnetism of component atoms using Pascal's constant. The diffuse reflectance spectra of the solid polymeric chelates were recorded on a Beckman DK-2A spectrophotometer with a solid reflectance attachment. $\mathrm{MgO}$ was employed as the reference compound. The number average molecular weight $(\overline{\mathrm{M}})$ of all the Co-ordination polymers were determined by method reported in earlier communications. ${ }^{34}$ Thermogravimetric analysis of Co-ordination polymers were carried on DuPont 950 TGA analyzer in air at a heating rate of $20^{\circ} \mathrm{C} / \mathrm{min}$

\section{Screening of antibacterial and antifungal activities}

\section{Antibacterial activities}

In vitro antibacterial screening of $\mathrm{CPHQ}$ and its Co-ordination polymers were studied against gram-positive bacteria (Bacillus subtilis and staphylococcus aureus) and gram-negative bacteria (Escherichia coli and Salmonella typhi) by cup-plate method $^{35}$ using nutrient agar as medium. In a typical procedure, molten nutrient agar kept at $45^{\circ} \mathrm{C}$ was then poured into Petri dishes and allowed to solidify. Then holes of 5 millimeter diameter were punched carefully using a sterile cork borer and these were completely filed with test solutions $(1 \mathrm{mg} / \mathrm{mL}$ in DMF). The diameter of the zone of inhibition for all the compounds was measured and the results were compared with the standard drug streptomycin of the same concentration as that of the test compound under identical conditions. ${ }^{36}$

TABLE 1. Analytical and spectral data of the CPHQ and its Co-ordination polymers.

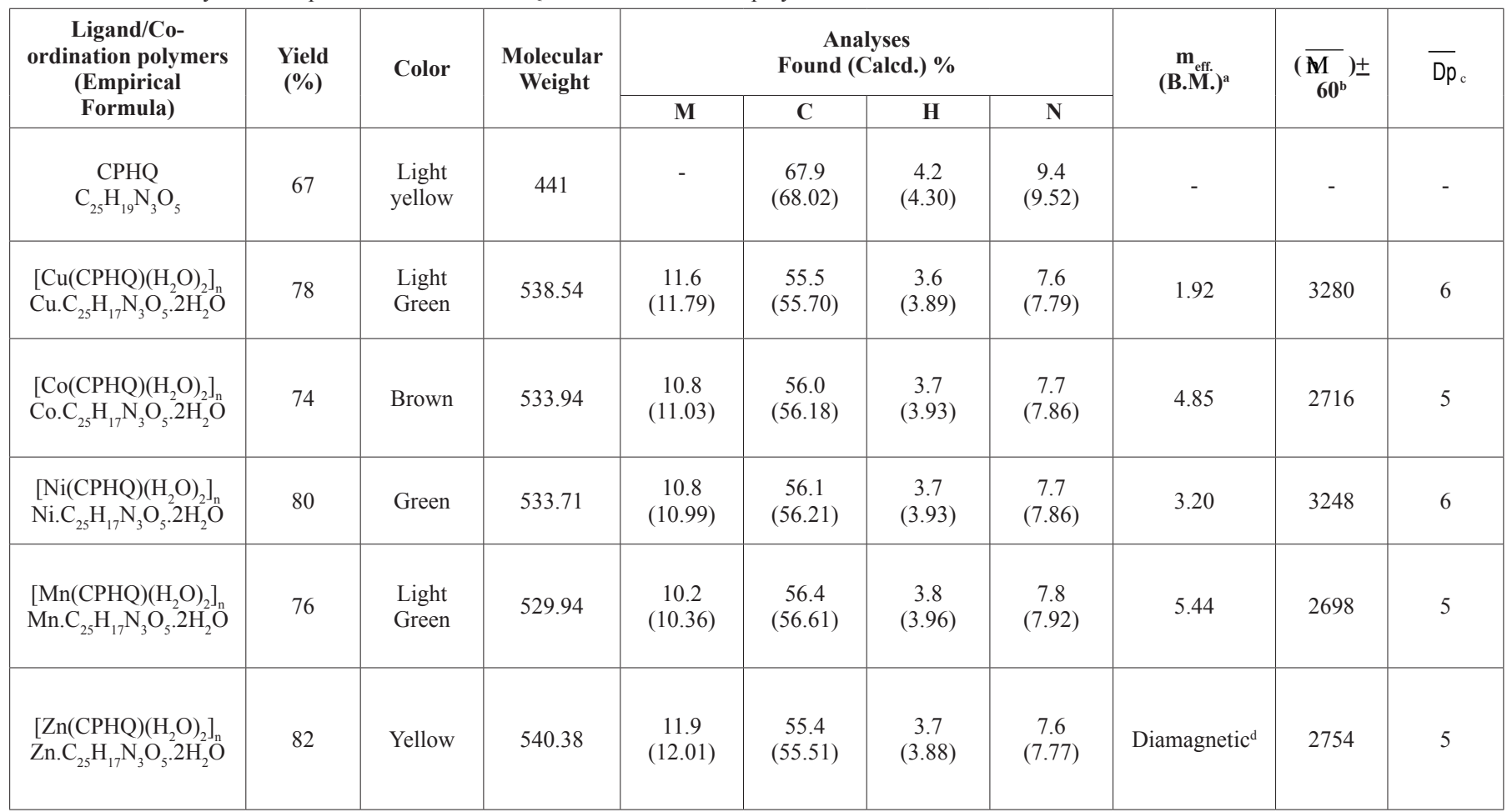

${ }^{\text {a }}$ Magnetic susceptibility; ${ }^{\mathrm{b}}$ Number average molecular weight ; ${ }^{\mathrm{c}}$ Average degree polymerization ; ${ }^{\mathrm{d}}$ Diamagnetic behaviour.

\section{Antifungal activities}

The antifungicidal activity of all the compounds was evaluated against penicillium expansum, Nigrospora Sp., Trichothesium Sp., and Rhizopus nigricum by cup-plate method cultured on potato-dextrose agar medium adapting similar procedure describe above. The plates were incubated at $37^{\circ} \mathrm{C}$ for 48 hours. The diameter of the zone of inhibition for all the compounds was measured and the results were compared with standard drug Chlotrimazole in the same experimental conditions. ${ }^{37}$

\section{RESULTS AND DISCUSSION}

The synthesis of the Bis-ligand, 5-[4-(2-carboxyphenyl carbonyl amino) phenyl carbonyl methyl amino)-8-hydroxyquinoline (CPHQ) has not been reported in the literature. All the metal complexes were sparingly soluble in common organic solvents but soluble in DMF, DMSO and Acetonitrile. The results of elemental analyses of Bis-ligand CPHQ and its Co-ordination polymers are agreed with those predicted on the molecular formula (Table 1). 
The analytical data indicates that the metal complexes are agreed well with 1:1 metal to ligand (M/L) stoichiometry. The structure of CPHQ and its Coordination polymers was confirmed by the elemental analysis, FTIR, ${ }^{1} \mathrm{H}-\mathrm{NMR}$ and ${ }^{13} \mathrm{C}-\mathrm{NMR}$, reflectance spectra, magnetic susceptibility measurements and TGA analysis. Elemental (CHN) analysis, physical properties and IR data provided good evidence that the chelates are polymeric in nature. ${ }^{38,39}$ Possible structure of the Co-ordination polymers is shown in scheme 1.

\section{Magnetic susceptibility}

The magnetic susceptibility measurements of the metal complexes were performed at room temperature (Table 1). The magnetic susceptibility value for $\mathrm{Cu}^{+2}$ complexes of the ligand CPHQ is 1.92 B.M., it is less than the normal value ${ }^{40}(1.84-2.20$ B.M.). The lowered magnetic moment value observed for $\mathrm{Cu}^{+2}$ complex under the present study is due to distorted octahedral geometry. ${ }^{41,42}$ On the other hand magnetic moment values of $\mathrm{Co}^{+2}$ and $\mathrm{Ni}^{+2}$ complexes indicate an octahedral geometry for these complexes. ${ }^{43}$ $\mathrm{Mn}^{+2}$ complex exhibited magnetic moment at 5.44 B.M. ${ }^{44}$ It indicates that the complex is high-spin type paramagnetic, it lies within the octahedral range. The obtained result is very close to spin value 5.90 B.M. as the ground term is ${ }^{6} \mathrm{~A}_{1 \mathrm{~g}}$ and thus supports the octahedral geometry. ${ }^{45}$

\section{Infrared spectra}

The IR spectrum of CPHQ shows a broad band at $3340 \mathrm{~cm}^{-1}$ attributed to the -OH stretching vibrations. The weak bands around 2862 and $2945 \mathrm{~cm}^{-1}$ may be due to asymmetric and symmetric stretching vibrations of methylene groups. The bands at $3400 \mathrm{~cm}^{-1}$ and $1710 \mathrm{~cm}^{-1}$ are due to $\mathrm{NH}(\mathrm{Sec})$ and $\mathrm{CO}$ group respectively. The bands around $1634,1575,1500$ and $1440 \mathrm{~cm}^{-1}$ are attributed to the 8 -hydroxyquinoline nucleus. ${ }^{18}$ The band at $1690 \mathrm{~cm}^{-1}$ is recognized $\mathrm{COOH}$ group. The bands around 1650,1610 and $1520 \mathrm{~cm}^{-1}$ are attributed to amide group. Comparison of the IR spectrum of the Bis-ligand CPHQ and those of the Co-ordination polymers reveals certain characteristic differences. The broad band at $3340 \mathrm{~cm}^{-1}$ for CPHQ has almost disappeared for the spectra of polymers. However, the weak band around $3200 \mathrm{~cm}^{-1}$ in the spectra of CPHQ$\mathrm{Co}^{2+}, \mathrm{CPHQ}-\mathrm{Ni}^{2+}, \mathrm{CPHQ}-\mathrm{Mn}^{2+}$ indicate the presence of water molecules which may have been strongly absorbed by the Co-ordination polymers. The C-O stretching in the ligand may be suggested due to the absorptions at 1366 and $1252 \mathrm{~cm}^{-1}$. In the complexes, these bands are shifted to 1347 and $1245 \mathrm{~cm}^{-1}$ respectively. These results indicate the formation of C-O-M bond. The peak at $1234 \mathrm{~cm}^{-1}$ in the ligand is assigned to $\mathrm{OH}$-bending of the phenolic moiety. This band is absent in the Co-ordination polymers. In addition to these bands, the spectrum of CPHQ has many characteristic absorption bands, which are identical to those that occur in 5-(4-phenyl carbonyl methyl amino)-8-hydroxy quinoline (PHQ) and phthalic anhydride. The new bands observed in the region $470-440 \mathrm{~cm}^{-1}$ and $430 \mathrm{~cm}^{-1}$ are probably due to the formation of M-O and M-N bonds respectively. ${ }^{46}$ Thus, it is possible that the oxygen and nitrogen atoms of 8-hydroxyquinoline groups are coordinated to the metal. ${ }^{47,48}$ From the above data the following structure has been proposed for the Co-ordination polymers shown in scheme 1.

${ }^{1} \mathrm{H}$ NMR and ${ }^{13} \mathrm{C}$ NMR spectra of the Bis-ligand (CPHQ)

${ }^{1} \mathrm{H}$ NMR spectrum shows signal at $\delta 4.8 \mathrm{ppm}(\mathrm{s}, 2 \mathrm{H})$ which is due to $-\mathrm{CH}_{2}$ protons Also single at $\delta 4.6,9.4 \mathrm{ppm}(\mathrm{s}, 2 \mathrm{H})$ due to $-\mathrm{NH}$ proton and single at $\delta 5.7 \mathrm{ppm}(\mathrm{s}, 1 \mathrm{H})$ due to $-\mathrm{OH}$ proton. The signal at $\delta 8.9-6.9 \mathrm{ppm}(\mathrm{m}, 13 \mathrm{H})$ is assign to aromatic protons of quinolone and phenyl moieties. A sharp peak at $\delta 11.3 \mathrm{ppm}(\mathrm{s}, 1 \mathrm{H})$ is assign to $-\mathrm{COOH}$ group. These all features confirm the proposed structure of CPHQ Bis-ligand.

In the ${ }^{13} \mathrm{C}$ NMR spectrum of CPHQ is observe a signal at $60.2 \mathrm{ppm}$ it is assign to methylene carbons. Signals at $164.6-185.8 \mathrm{ppm}$ are assign to $\mathrm{C}=\mathrm{O}$ carbons. The signals observe between $112.5-150.6 \mathrm{ppm}$ are assigned to aromatic carbons of the ligand.

Electronic spectra

The diffusion electronic spectrum of $\mathrm{Cu}^{+2}, \mathrm{Co}^{+2}, \mathrm{Ni}^{+2}, \mathrm{Mn}^{+2}$ and $\mathrm{Zn}^{+2}$ complexes were recorded in DMF. The diffusion electronic spectrum of $\mathrm{CPHQ}-\mathrm{Cu}^{2+} \mathrm{Co}$-ordination polymers shows two broad bands at $15,380 \mathrm{~cm}^{-1}$ and $22,730 \mathrm{~cm}^{-1}$. The first bands may be due to ${ }^{2} \mathrm{~T}_{2 \mathrm{~g}} \mathrm{a}^{2} \mathrm{E}_{\mathrm{g}}$ transition, while the second may be due to charge transfer. The first band assigns distorted octahedral structure for the CPHQ- $\mathrm{Co}^{2+}$ complex. The higher value of $\mu_{\text {of }}$ of the CPHQ$\mathrm{Cu}^{2+}$ polymer support distorted octahedral structure ${ }^{49,50}$ The $\mathrm{CPHQ}-\mathrm{Ni}^{2+}$ and $\mathrm{CPHQ}-\mathrm{Co}^{2+}$ polymers give two absorption bands at 17,250 and $24,000 \mathrm{~cm}^{-1}$ and at 17,240 and $23730 \mathrm{~cm}^{-1}$ respectively. These bands can be assigned to ${ }^{4} \mathrm{~T}_{1 \mathrm{~g}} \mathrm{a}^{2} \mathrm{~T}_{2 \mathrm{~g}}$ and ${ }^{4} \mathrm{~T}_{1 \mathrm{a}} \mathrm{a}^{4} \mathrm{~T}_{\mathrm{lg}(\mathrm{P})}$ transitions respectively. The absorption bands and the values of $\mu_{\text {eff }}$ indicate an octahedral configuration for the CPHQ- $\mathrm{Ni}^{2+}$ and CPHQ- $\mathrm{Co}^{2+}$ polymers. ${ }^{51,52}$ The spectrum of CPHQ- $\mathrm{Mn}^{2+}$ showed weak bands at 16,474 , 17,690 and $23,164 \mathrm{~cm}^{-1}$ assigned to the transitions $6_{\mathrm{Alg}} \rightarrow 4_{\mathrm{Tlg}}(4 \mathrm{G}), 6_{\mathrm{Alg}} \rightarrow$ ${ }_{4 \mathrm{~T} 2 \mathrm{~g}}(4 \mathrm{G})$ and $6_{\mathrm{Alg}} \rightarrow 4_{\mathrm{Alg}}, 4_{\mathrm{Eg}}$ respectively, suggesting an octahedral structure for the $\mathrm{Mn}^{2+}$ complex. ${ }^{52}$ The spectrum of the $\mathrm{Zn}^{2+}$ complex is not well resolved, so it is not interpreted, but its $\mu_{\text {eff }}$ value shows that it is diamagnetic as expected.

Thermogravimetric Analyses

The thermal behavior of Co-ordination polymers and parent bis-ligand was investigated by TGA analysis. The TGA data of all the samples are presented in Table 2. The weight loss of the polymer samples at different temperature indicates that the degradation of the polymers is noticeable beyond $250^{\circ} \mathrm{C}$.

Table 2. Thermogravimetric analysis of Bis-ligand (CPHQ) and their Co-ordination polymers.

\begin{tabular}{|c|c|c|c|c|c|c|c|c|}
\hline \multirow{2}{*}{ Ligand/ Co-ordination polymers } & \multicolumn{7}{|c|}{ \% Weight loss at different temperature $\left({ }^{\circ} \mathbf{C}\right)$} & \multicolumn{2}{|c|}{$\begin{array}{c}\text { Activation energy } \\
\text { (Kcal/mol) }\end{array}$} \\
\cline { 2 - 10 } & $\mathbf{1 0 0}$ & $\mathbf{2 0 0}$ & $\mathbf{3 0 0}$ & $\mathbf{4 0 0}$ & $\mathbf{5 0 0}$ & $\mathbf{6 0 0}$ & $\mathbf{7 0 0}$ & 9.7 \\
\hline $\mathrm{CPHQ}$ & 1.4 & 6.8 & 40.4 & 56.9 & 60.4 & 63.1 & 66.0 & 6.6 \\
\hline$\left[\mathrm{CuCPHQ}\left(\mathrm{H}_{2} \mathrm{O}\right)_{2}\right]_{\mathrm{n}=2}$ & 1.3 & 8.1 & 11.6 & 26.4 & 30.5 & 33.5 & 37.2 & 8.6 \\
\hline$\left[\mathrm{CoCPHQ}\left(\mathrm{H}_{2} \mathrm{O}\right)_{2}\right]_{\mathrm{n}=2}$ & 5.7 & 6.9 & 12.8 & 26.3 & 38.0 & 43.2 & 49.9 & 8.7 \\
\hline$\left[\mathrm{NiCPHQ}\left(\mathrm{H}_{2} \mathrm{O}\right)_{2}\right]_{\mathrm{n}=2}$ & 4.6 & 8.6 & 13.7 & 24.5 & 39.2 & 42.3 & 49.4 & 8.4 \\
\hline$\left[\mathrm{MnCPHQ}\left(\mathrm{H}_{2} \mathrm{O}\right)_{2}\right]_{\mathrm{n}=2}$ & 3.8 & 6.3 & 12.1 & 22.6 & 31.4 & 34.6 & 36.2 & \\
\hline$\left[\mathrm{ZnCPHQ}\left(\mathrm{H}_{2} \mathrm{O}\right)_{2}\right]_{n=2}$ & 4.1 & 7.5 & 17.6 & 33.9 & 41.8 & 49.1 & 52.3 & \\
\hline
\end{tabular}

A very slight decrease in weight loss depicted from the thermogram in the temperature range $50-150^{\circ} \mathrm{C}$ for the parent ligand may be attributed to loosely bonded moisture. However, the initial slow weight loss occurring below 150 ${ }^{\circ} \mathrm{C}$ in all of the Co-ordination polymers may be attributed to the removal of water.

Inspection of the thermograms of all coordinated polymer samples reveals appreciable weight loss in the range 150 to $270{ }^{\circ} \mathrm{C}$ which might be due to metal-Co-ordinate water molecules (Scheme 1) ${ }^{34}$ It was reported that the water molecules are coordinated to the metal ions. ${ }^{53}$ The rate of degradation becomes maximum at temperature between $400^{\circ} \mathrm{C}$ and $500^{\circ} \mathrm{C}$. Above this temperature, Co-ordination polymers are most stable and each Co-ordination polymers loses about $55 \%$ of its weight when it is heated at $700{ }^{\circ} \mathrm{C}$ originating metal oxides. ${ }^{47}$

The thermodynamic activation parameter of the decomposition process of the Co-ordination polymers such as energy of activation (Ea) and order of reaction $(\mathrm{n})$, were evaluated graphically by employing the Freeman-Carroll method $^{33}$ using the following relation:

\section{$[(-\mathrm{Ea} / 2.303 \mathrm{R}) \Delta(1 / \mathrm{T})] \Delta \log \mathrm{Wr}=-\mathrm{n}+\Delta \log (\mathrm{dW} / \mathrm{dt}) \Delta \log \mathrm{Wr}$}

where $\mathrm{T}$ is the temperature in $\mathrm{K}, \mathrm{R}$ is gas constant, $\mathrm{Wr}=\mathrm{Wc}-\mathrm{W}$; $\mathrm{Wc}$ is the weight loss at the completion of the reaction and $\mathrm{W}$ is the total mass loss up to time t. Ea and $\mathrm{n}$ are the energy of activation and order of reaction respectively. A typical curve of $[\Delta \log (\mathrm{dw} / \mathrm{dt}) / \Delta \log \mathrm{Wr}]$ vs $[\Delta(1 / \mathrm{T}) / \Delta \log \mathrm{Wr}]$ for the $\mathrm{Co}^{2+} \mathrm{Co}-$ ordination polymer is shown in Figure 1. The slope of the plot gave the value of $\mathrm{Ea} / 2.303 \mathrm{R}$ and the order of reaction was determined from the intercept. 


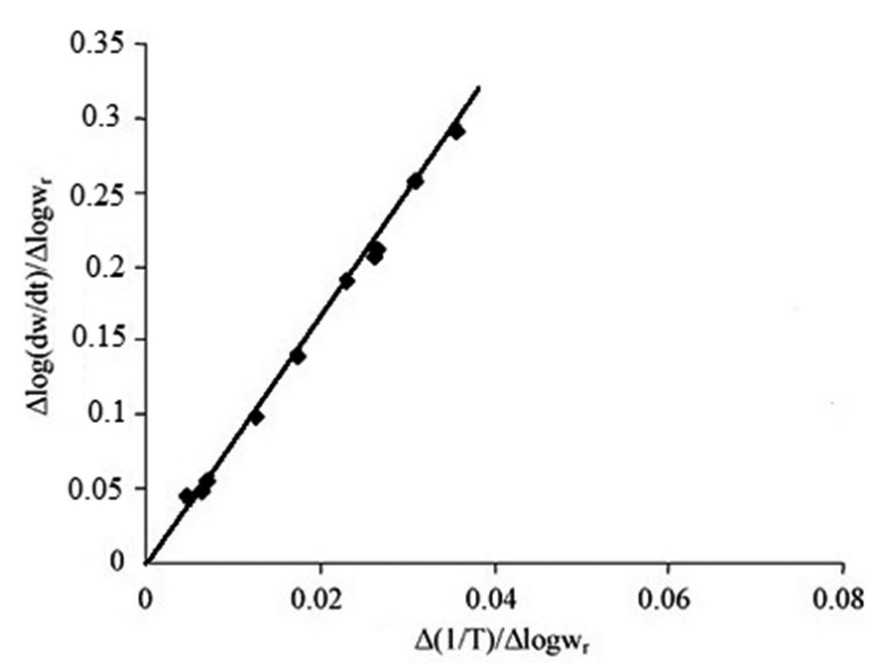

The kinetic parameter, especially activation energy (Ea) is helpful in assigning the strength of the Co-ordination polymers. The calculated Ea values of Co-ordination polymers indicate that volatile gas is produce in the range of 6.6-9.5 $\mathrm{kcalmol}^{-1}$. The relatively high value of Ea (Table 2) indicates that the ligand is strongly bonded to the metal ion. ${ }^{54-55}$ Based on the activation energy values, the thermal stability of the Co-ordination polymers in the decreasing order is: $\mathrm{Mn}>\mathrm{Co}>\mathrm{Ni}>\mathrm{Zn}>\mathrm{Cu}^{56}$

Antimicrobial Activity of the Bis-ligand and its Co-ordination Polymers

All the novel synthesized compounds and standard drugs were prepared in freshly distilled DMF. The zone of inhibition evaluated was negligible. These data reveal that the Bis-ligand $\mathrm{CPHQ}$ and its Co-ordination polymers shows weak to good antimicrobial activity (Table 3 ).

These data are compared with the standard drug streptomycin, the Bisligand and its $\mathrm{Cu}^{2+}$ and $\mathrm{Co}^{2+}$ complexes showed weakly active against the both organisms with zones of inhibition 9-11 $\mathrm{mm}$ and 12-14 mm respectively. On the other hand, the $\mathrm{Ni}^{2+}$ and $\mathrm{Mn}^{2+}$ complexes can be classified of moderately active compared to its ligand with zone of inhibition $15-17 \mathrm{~mm}$ while the $\mathrm{Zn}^{2+}$ complex exhibited good activity with zone of inhibition $18-20 \mathrm{~mm}$.

Figure 1. Freeman-Carroll plot for thermal degradation of $[\mathrm{CoCPHQ}(\mathrm{H} 2 \mathrm{O}) 2]$ n complexe.

Table 3. Antibacterial activities of Bis-ligand (CPHQ) and their Co-ordination polymers.

\begin{tabular}{|c|c|c|c|c|}
\hline \multirow{3}{*}{$\begin{array}{c}\text { Ligand/ } \\
\text { Co-ordination polymers }\end{array}$} & \multicolumn{3}{|c|}{ Zone of Inhibition (mm) } & \\
\hline & \multicolumn{2}{|c|}{ Gram +Ve } & & \\
\hline & $\begin{array}{c}\text { Bacillus } \\
\text { subtilis }\end{array}$ & $\begin{array}{c}\text { Staphylococcus } \\
\text { aureus }\end{array}$ & $\begin{array}{c}\text { Salmonella } \\
\text { typhi }\end{array}$ & Escherichia coli \\
\hline$\left[\mathrm{CuCPHQ}\left(\mathrm{H}_{2} \mathrm{O}\right)_{2}\right]_{\mathrm{n}}$ & 12 & 13 & 14 & 13 \\
\hline$\left[\mathrm{CoCPHQ}\left(\mathrm{H}_{2} \mathrm{O}\right)_{2}\right]_{\mathrm{n}}$ & 13 & 12 & 13 & 14 \\
\hline$\left[\mathrm{MnCPHQ}\left(\mathrm{H}_{2} \mathrm{O}\right)_{2}\right]_{\mathrm{n}}$ & 17 & 16 & 16 & 15 \\
\hline$\left[\mathrm{ZnCPHQ}\left(\mathrm{H}_{2} \mathrm{O}\right)_{2}\right]_{\mathrm{n}}$ & 19 & 20 & 18 & 20 \\
\hline Streptomycin & 23 & 24 & 24 & 25 \\
\hline DMF (Control) & 00 & 00 & 00 & 00 \\
\hline Bore size & 08 & 08 & 08 & 08 \\
\hline
\end{tabular}

The antifungal activity results revealed that the ligand CPHQ and its Co-ordination polymers show weak to good activity (Table 4). Bis-ligand and its Cu${ }^{2+}$ and $\mathrm{Co}^{2+}$ complexes showed weak active with zone of inhibition $12-14 \mathrm{~mm}$. The $\mathrm{Ni}^{2+}$ and $\mathrm{Zn}^{2+}$ complexes show moderate activity with zone of inhibition $15-17 \mathrm{~mm}$, while the $\mathrm{Mn}^{2+}$ complex exhibited good activity with zone of inhibition $18-20 \mathrm{~mm}$.

Table 4. Antifungal activity of Bis-ligand (CPHQ) and their Co-ordination polymers.

\begin{tabular}{|c|c|c|c|c|}
\hline \multicolumn{5}{|c|}{ Zone of Inhibition at 1000 ppm (\%) } \\
\hline $\begin{array}{c}\text { Ligand/ } \\
\text { Co-ordination polymers }\end{array}$ & Penicillium Expansum & Nigrospora Sp. & Trichothesium Sp. & $\begin{array}{c}\text { Rhizopus } \\
\text { Nigricum }\end{array}$ \\
\hline $\mathrm{CPHQ}$ & 08 & 08 & 09 & 10 \\
\hline$\left[\mathrm{CuCPHQ}\left(\mathrm{H}_{2} \mathrm{O}\right)_{2}\right]_{\mathrm{n}}$ & 14 & 13 & 13 & 12 \\
\hline$\left[\mathrm{CoCPHQ}\left(\mathrm{H}_{2} \mathrm{O}\right)_{2}\right]_{\mathrm{n}}$ & 12 & 12 & 14 & 13 \\
\hline$\left[\mathrm{NiCPHQ}\left(\mathrm{H}_{2} \mathrm{O}\right)_{2}\right]_{\mathrm{n}}$ & 16 & 15 & 17 & 16 \\
\hline$\left[\mathrm{MnCPHQ}\left(\mathrm{H}_{2} \mathrm{O}\right)_{2}\right]_{\mathrm{n}}$ & 19 & 18 & 20 & 16 \\
\hline$\left[\mathrm{ZnCPHQ}\left(\mathrm{H}_{2} \mathrm{O}\right)_{2}\right]_{\mathrm{n}}$ & 15 & 17 & 24 & 16 \\
\hline Chlotrimazole & 24 & 26 & 25 \\
\hline
\end{tabular}




\section{CONCLUSION}

The novel 5-[4-(2-carboxyphenyl carbonyl amino)-phenyl-4-carbonyl methyl amino)-8-hydroxyquinoline (CPHQ) and its octahedral metal (II) complexes (1: 1 metal to ligand ratio) were synthesized and characterized. Further, the Co-ordination polymers were thermally more stable than the ligand. All the Co-ordination polymers showed good antibacterial and antifungal activities compared to CPHQ ligand due to the insertion of the metal ions. The information regarding geometry of the complexes was obtained from their electronic and magnetic moment values. The magnetic moment values indicate an octahedral geometry.

\section{REFERENCES}

1. H. M. Shukla, A. I. Shah, P. J. Shah and D. S. Raj, Der Pharmacia Sinica 1(3), 165, (2010).

2. H. M. Shukla, A. I. Shah, P. J. Shah and D. S. Raj, J. Chem. Pharm. Res. 2(5), 169, (2010).

3. H. Horowitz and J.P. Perrors, J. Inorg. Nuclei. Chem. 26, 139, (1964).

4. A. I. Shah, H. M. Shukla, P. J. Shah and D. S. Raj, Chemistry \& Biology Interface 2(4), 234, (2012).

5. A. M. Karampurwala, R.P. Patel and J.R. Shah, Angew. Makromol. Chem. 87, 87, (1980).

6. A. I. Shah, H. M. Shukla, P. J. Shah and D. S. Raj, Der Chemica Sinica 1(3), 73, (2010).

7. K. D. Patel and S.C. Panchani, Ultra Scientist Physical Science 15, 195, (2003).

8. H. S. Patel, R. B. Dixit and T. B. Shah, Int. J. Polym. Material 49, 27, (2001).

9. A. D. Patel, R. S. Patel and G. R. Patel, E-Journal of Chemistry 7(3), 1023, (2010).

10. D. A. Pearce, N. Jotterand, I. S. Carrico, B. Imperiali, J. Am. Chem. Soc. 123, 5160, (2001)

11. M. Albrecht, K. Witt, R. Frohlich and O. Kataeva, Tetrahedron 58, 56, (2002).

12. L. H. Schmidt, Ann. Rev. Microbiol. 427, 23, (1969).

13. L. M. Leung, W.Y. Lo, S. K. So, K. M. Lee and W. K. Choi, J. Am. Chem. Soc. 122, 5640, (2000).

14. K. D. Patel and H. S. Patel, Der Pharmacia Lettre. 3(1), 356, (2011).

15. N. Manolova, M. Ignatova and I. Rashkov, Eur. Polymer J. 34, 1133, (1998).

16. S.Q. Zang, Y. Su, Y. Z. Li and H.Z. Zhu, Inorg. Chem. 45, 2972, (2006).

17. B. Dixit, R. Dixit and D. Desai, Journal of Polymer Research 17(4), 481, (2010).

18. D. Prakash, A. P. Roy and O.P. Gupta, Asian J. Chem. 6, 956, (1994).

19. D. Prakash and A. K. Yadav, Asian J. Chem. 11(3), 1037, (1999).

20. T. B. Shah, M. M. Raj, L. M. Raj and H.S. Patel, Eur. Polym. J. 14(2), 199, (1998).

21. N. Angelova, N. Manolova and I. Rashkov, Eur. Polym. J. 31, 741, (1995).

22. M. Bakova, Ts. Petrova, N. Manolova and I. Rashkov, Eur. Polym. J. 32, $569,(1996)$.

23. M. Bankova, N. Manolova, N. Markova, T. Radoucheva, K. Deilova and I. Rashkova, Eur. Polymeric J. 34, 247, (1998).

24. M. Bankova, N. Mancova and I. Rashkova, Eur. Polym. J. 30, 1159, (1994).

25. A. I. Shah, H. M. Shukla, P. J. Shah and D. S. Raj, Elixir Chem. Phys. 44 7378, (2012).

26. T. B. Shah, L.M. Raj and R.B. Dixit, Int. J. Polym. Mat. 52, 9, (2003).

27. G. Dayakar and P. Lingaiah, Asian J. Chem. 9, 179, (1997).

28. A. I. Shah, H. M. Shukla, P. J. Shah and D. S. Raj, J. Chem. Pharm. Res. 2(5), 526, (2010).

29. M.Viswanathan and G. Krishan, Asian J. Chem. 16, 169, (2000).

30. A. Singh and J. Bhanderi, Rasayan J.Chem. 2(4), 846, (2009).

31. Y. T. Partt, N. L. Dranke, J. Am. Chemical. Soc. 82, 1155, (1960).

32. W. Prodinger and O. Suobodda, Montas. Chem. 85, 23, (1960).

33. F. Kunckell, Ber. Disch. Chem. Ges. 34, 128, (1900).

34. T. B. Shah, H.S. Patel, R.B. Dixit and B.C. Dixit, Int. J. Polym. Anal. Charact. 8, 369, (2003).

35. A. L. Barry, The Antimicrobic Susceptibility Test: Principle and Practices, Illus Lea \& Febiger Ed., Philadelphia, U.S.A., 1976 ; pp. 180

36. F. Simoncini, R. Rangone and C. Calanni, Franance Ed., 23(10), 559, (1968).
37. H.W.Seely, P.J. Van Demark, Microbes in Action, Laboratory of Microbilogy $3^{\text {rd }}$ Ed., W.H. Freeman and Co., U.S.A., 1981 ; pp. 385.

38. R. Pohl, V. Montes, A. J. Shinar and Jr. P.Anzenbacher, J. Org. Chem. 69, $1723(2004)$.

39. R. D. Patel, S.R. Patel and H.S. Patel, Eur. Polym. J. 23(3), 229, (1987).

40. A. Kriza, C. Spena and M. Pleniceance, J. Indian Chem. Soc. 77, 83, (2000)

41. M. B. Halli and Z. S. Qureshi, Indian J. Chem. 43A, 2347, (2000).

42. F. A. Cotton, G. Wilkinson, Advanced Inorganic Chemistry, $2^{\text {nd }}$ Ed. Wiley Estern, New York, 1967.

43. M. M. Bekhet, K. M. Ibrahim, Synth. React. Inorg. Met-Org. Chem. 16, $1135,(1986)$

44. T. Singh, R. N. Singh, Synth. React. Inorg. Met-Org. Chem. 19(3), 251, (1989).

45. A. P. Grinsberg, R. C. Sherwood and K. E. Koube, J. Inorg. Nucl. Chem. 29, 353, (1967)

46. D. H. Jani, H. S. Patel, H. Keharia and C.K. Modi, Appl. Org. Chem. 24, 99, (2010).

47. S. H. Patel, H. M. Parekh, P. K. Panchal and M. N. Patel, J. Macro. Sci., Part A: Pure Appl. Sci. 44, 599, (2007).

48. C. K. Modi, Spectrochimica Acta Part A: Molecular Biomecular Spectroscopy 71, 1741, (2009).

49. D. C. Patel and P.K. Bhattacharya, J. Indian Chem. Soc. 49, 1041, (1972).

50. D. Oza, K. N. Kaul and R. K. Mehta, Indian J. Chem. 7, 927, (1996).

51. J. Lewis, R. S. Wilkins, Modern Co-ordination Chemistry, WileyInterscience, 1960; pp. 290.

52. R. Papplardo, J. Chem. Phys. 33, 613, (1960).

53. H. Icbudak and V. T. Yilmaz, J. Therm. Analz. 53, 843, (1998).

54. J. Garcice, M. C. Molla, J. Borras and E. Escriva, Thermochim. Acta 106, $155,(1986)$.

55. C. K. Modi and M.N. Patel, J. Therm. Anal. Cal. 94(1), 247, (2008).

56. H. M. Parekh, P. K. Panchal and M. N. Patel, J. Therm. Anal. Cal. 86(3), $803,(2006)$. 